\title{
The generalist tick Ixodes ricinus and the specialist tick Ixodes trianguliceps on shrews and rodents in a northern forest ecosystem- a role of body size even among small hosts
}

\author{
Atle Mysterud $^{1 *}$, Ragna Byrkjeland ${ }^{1}$, Lars Qviller ${ }^{1,2}$ and Hildegunn Viljugrein ${ }^{1,2}$
}

\begin{abstract}
Background: Understanding aggregation of ticks on hosts and attachment of life stages to different host species, are central components for understanding tick-borne disease epidemiology. The generalist tick, Ixodes ricinus, is a wellknown vector of Lyme borrelioses, while the specialist tick, lxodes trianguliceps, feeding only on small mammals, may play a role in maintaining infection levels in hosts. In a northern forest in Norway, we aimed to quantify the role of different small mammal species in feeding ticks, to determine the extent to which body mass, even among small mammals, plays a role for tick load, and to determine the seasonal pattern of the two tick species.

Methods: Small mammals were captured along transects in two nearby areas along the west coast of Norway. All life stages of ticks were counted. Tick load, including both prevalence and intensity, was analysed with negative binomial models.

Results: A total of 359 rodents and shrews were captured with a total of 1106 I. ricinus (60.0 \%) and 737 I. trianguliceps (40.4\%), consisting of $98.2 \%$ larvae and $1.8 \%$ nymphs of I. ricinus and $91.2 \%$ larvae, $8.7 \%$ nymphs and $0.1 \%$ adult females of I. trianguliceps. Due to high abundance, Sorex araneus fed most of the larvae of both tick species (I. ricinus $61.9 \%$, I. trianguliceps $64.9 \%$ ) with Apodemus sylvaticus (I. ricinus $20.4 \%$, I. trianguliceps $10.0 \%$ ) and Myodes glareolus (I. ricinus $10.9 \%$, I. trianguliceps $9.5 \%$ ) as the next most important hosts. Individual A. sylvaticus and M. glareolus had higher infestation intensity than S. araneus, while Sorex minutus had markedly lower infestation intensity. The load of I. ricinus larvae and nymphs was related to body mass mainly up to $\sim 10 \mathrm{~g}$, while the load of I. trianguliceps was less dependent of body mass. The load of I. trianguliceps was higher in spring than in fall, while the seasonal pattern was reversed for I. ricinus with higher loads in fall.

Conclusions: Body mass was important for explaining load of I. ricinus mainly up to a body mass of $\sim 10 \mathrm{~g}$ across a range of smaller mammalian hosts. Consistent with earlier work elsewhere in Europe, we found the highest tick infestation intensity on the wood mouse A. sylvaticus. However, this rodent species fed only $20.4 \%$ of all I. ricinus larvae, while the much more abundant S. araneus fed $61.9 \%$. Our study emphasizes an important quantitative role of the common shrew S. araneus as a main host to I. ricinus larvae and to both I. trianguliceps larvae and nymphs. The partly seasonal distinct attachment pattern of I. ricinus and I. trianguliceps is evidence for niche separation.
\end{abstract}

Keywords: Ixodes ricinus, Ixodes trianguliceps, Ticks, Tick-borne diseases, Rodents, Voles, Shrews, Tick load, Host body size, Host selection, Norway

\footnotetext{
* Correspondence: atle.mysterud@ibv.uio.no

'Department of Biosciences, Centre for Ecological and Evolutionary Synthesis

(CEES), University of Oslo, P.O. Box 1066 Blindern, NO-0316 Oslo, Norway

Full list of author information is available at the end of the article
} 


\section{Background}

The generalist sheep tick Ixodes ricinus in Europe is the principal vector of several pathogens causing disease in humans and livestock. This includes the pathogenic genospecies from the Borrelia burgdorferi sensu lato complex causing Lyme borrelioses [1] and the virus causing tick-borne encephalitis (TBE) [2] in humans, Anaplasma phagocytophilum causing tick-borne fever in livestock [3] and the protozoan Babesia divergens causing babesiosis in cattle. Most parasites [4], including Ixodes ticks [5-7], are typically aggregated on certain species and individuals, and an important element in understanding the epidemiology of the tick-borne diseases is identifying which species and individuals are feeding most of the ticks. The I. ricinus life cycle has three active life stages requiring a blood meal to moult into the next stage or to reproduce. The larvae and nymphs feed on a wide range of different sized hosts [8], while the adult female tick requires a blood meal from a large host to complete the life cycle. Small mammals are considered an especially important group due to their reservoir competence for pathogens (mainly Borrelia afzelii) causing Lyme borrelioses [9].

Ticks, vertebrates and associated pathogens form complex ecological networks [10]. Specialized tick species can also play a role in the epidemiology by maintaining high infection levels in the reservoir hosts, even if they do not act as vectors of disease to humans or livestock. One such example is the nest-dwelling rodent specialist, Ixodes trianguliceps that do not act as direct vectors for pathogens causing human or livestock diseases (as they reside in burrows) [11]. It has been shown that I. trianguliceps may play a role in maintaining high infection levels in the reservoir hosts with regards to Babesia microti [12] and Anaplasma phagocytophilum [13, 14]. Another tick species (Ixodes neotomae) specialized on rodents in California showed a similar transmission role with regard to Borrelia [15]. I. trianguliceps is associated with distinct $A$. phagocytophilum genotypes in central Europe [16] and Siberia [17]. All life stages of I. trianguliceps are expected to be on small mammal hosts, but in addition, body mass differences among these small mammals were also shown to have an effect on host selection of different stages of I. trianguliceps [18].

There are many studies of tick loads on small mammals from endemic areas of the USA $[5,19]$ and in central [20-22] and eastern [23-25] Europe, considered endemic areas for Lyme borrelioses. I. ricinus and Lyme borrelioses are currently spreading towards higher latitudes of Scandinavia [26-28]. Main hosts in Norway are known mainly from qualitative evidence [29]. There is one quantitative study, however it is limited to Apodemus spp. and ticks [30]. The objective of this study was twofold; (1) to quantify the load of I. ricinus and I. trianguliceps ticks on species of shrews and rodents in a northern area of Lyme borrelioses, and hence to understand the quantitative role of different species in feeding ticks, and (2) to determine the extent to which body mass could explain variation in tick load among species and individuals.

\section{Methods}

Study area

The study area is located in the western part of southern Norway, in Førde and Askvoll municipalities in Sogn \& Fjordane county, close to the small town Førde $\left(61^{\circ} 27^{\prime} 2^{\prime \prime} \mathrm{N}\right.$, $\left.5^{\circ} 51^{\prime} 15^{\prime \prime} \mathrm{E}\right)$. The area lies mainly within the boreonemoral vegetation zone [31]. The bedrock is dominated by gneiss, granite, and other plutonic rock types, with limited coastal areas consisting of distinctive remnants of less modified sediments, such as conglomerate and sandstone. The region consists of mixed forests with deciduous woodland in the south facing slopes, with birch (Betula spp.), alder (Alnus incana), grass and herbs as the dominating vegetation. Other parts are dominated by Scots pine (Pinus sylvestris) together with planted Norway spruce (Picea abies). The study area is known for its mild winters and cold summers, with an average yearly precipitation of $2270 \mathrm{~mm}$ and an average temperature of $6.0{ }^{\circ} \mathrm{C}$ between 1961 and 1990 (http://met.no; Norwegian meteorological station no. 57170).

\section{Capture of small mammals}

Rodents and shrews were captured along two transects in Angedalen (slightly inland; mean distance from fjord $9.1 \mathrm{~km}$ ) and west of Førde city (termed Førde hereafter; coast; mean distance from fjord $2.8 \mathrm{~km}$ ), Førde and Askvoll municipalities, Sogn \& Fjordane county, Norway, during spring (2nd-5th of June) and fall (1st-4th of September) 2014. The trapping stations were spaced out with a minimum of $500 \mathrm{~m}$ in between to avoid depletion of the populations. Four traps were spaced out in the corners of a $15 \mathrm{~m}$ $\times 15 \mathrm{~m}$ square at each station according to the small quadrate method [32]. The traps were placed in natural structures or close to holes in the ground maximum $2 \mathrm{~m}$ from the square corners to enhance local capture probability. All traps were live traps of type "Ugglan" baited with carrots (for water) and oat (for food) on the first day of fieldwork. Food and water reserves would allow the rodents to survive for at least $24 \mathrm{~h}$. The traps were baited the first day, and operated for three consecutive days. All traps were controlled every day. Small mammals captured were sacrificed (cervical dislocation) and transferred to an individual zip-lock plastic bag, marked with station number, trap number and date. All bags were stored in a freezer for later observation.

All small mammals were weighed and identified morphologically to species level. A representative subsample of animals was identified with assistance from a rodent specialist (Torbjørn H. Ergon). All ticks on the hosts were removed from the captured rodents and shrews, and identified 
morphologically to species level, and characterized by the life stages larva, nymph, adult female or adult male [33]. The identification of a representative subsample of ticks was checked by a tick specialist (Reidar Mehl [29]).

We define the term "prevalence" as the \% of captured individuals with ticks, "intensity" as the number of ticks on a given host, and the "mean intensity" as the mean number of ticks among hosts with ticks [34]. We use the term parasite or tick "load" as a more general term for the whole pattern of parasitism including both prevalence and intensity.

\section{Questing tick collecting}

Questing I. ricinus were sampled at every trapping station, once during spring and fall 2013-2014 using the cloth-lure technique [35]. A cotton towel $(50 * 100 \mathrm{~cm})$ was attached to a rod and dragged over the vegetation [36]. Each of the transects started from the middle of one side in the $15 \mathrm{~m}^{*} 15 \mathrm{~m}$ square, was $10 \mathrm{~m}$ long and $2 \mathrm{~m}$ wide, and was directed away from the square centre. A total area of $20 \mathrm{~m}^{2}$ was flagged and ticks were removed from the towel, counted and identified to life stages after every $2 \mathrm{~m}$ of flagging.

\section{Statistical analyses}

Statistical analyses were conducted in R version 3.1.2 [37]. We used negative binomial models run in library glmmADMB [38]. We ran 4 separate models with load of $I$. ricinus and $I$. trianguliceps larvae and nymphs as response variables. Covariates were species, log-transformed body mass, location (Angedalen/Førde), and season (spring/fall), while trapping station was included as a random term. Neomys fodiens was excluded from analysis due to low sample size (Table 1). We used Akaike Information Criterion (AIC) for model selection using a combination of backward and forward selection procedures. Adding zero inflation did not improve model fit [39]. For questing tick data, we used abundance of nymphs as response, i.e. the number of ticks collected for each $20 \mathrm{~m}^{2}$ transect, and year (2013/1014), season (spring/fall) and location (Angedalen/Førde) as fixed effects with trapping station as a random term.

\section{Results}

We trapped 359 individuals of 7 species of small mammals (Table 1). They had in total 1106 I. ricinus $(60.0 \%)$ and 737 I. trianguliceps (40.4\%), consisting of 1086 larvae $(98.2 \%)$ and 20 nymphs (1.8\%) of I. ricinus and 672 larvae (91.2 \%), 64 nymphs (8.7\%) and 1 adult female $(0.1 \%)$ of I. trianguliceps. The four species of rodents had high prevalence of ticks ( $>80 \%)$, while Sorex araneus $(71.0 \%$, host $n=232)$, Neomys fodiens $(66.7 \%$, host $n=3)$ and particularly Sorex minutus $(34.2 \%$, host $n=31)$ had lower prevalence. S. araneus fed most of the larvae of both tick species (I. ricinus 61.9 \%, I. trianguliceps $64.9 \%$ ) with
Apodemus sylvaticus (I. ricinus $20.4 \%$ and I. trianguliceps $10.0 \%$ ) and Myodes glareolus (I. ricinus $10.9 \%$ and I. trianguliceps $9.5 \%$ ) as the next most important hosts (Table 2). In a simple model for load of I. ricinus larvae with species as categorical (controlling also for season), A. sylvaticus and M. glareolus had markedly higher load than S. araneus, while S. minutus had markedly lower load (Table 2).

We found co-feeding I. ricinus larvae and nymphs on 8 individuals, all but one captured during fall. Only 3 of these individuals, A. sylvaticus (104 larvae, 2 nymphs), $M$. agrestis (20 larvae, 1 nymph) and $S$. araneus (21 larvae, 1 nymph), had more than 10 larvae together with at least one nymph (the conditions required for TBE persistence), while the remaining 5 individuals had 1-4 larvae. For I. trianguliceps, 21 individuals had co-feeding larvae and nymphs (4 in spring, 17 in fall), with only 2 individuals having more than 10 larvae together with at least 1 nymph (M. glareolus: 14 larvae, 2 nymphs; $S$. araneus: 15 larvae, 3 nymphs).

Model selection results are presented in Appendix 1: Table 3. The best model for load of I. ricinus larvae included (log) body mass, species and season, but did not include location. Load of I. ricinus larvae increased with (log) body mass, but note that the effect of body mass was mainly up to $\sim 10 \mathrm{~g}$, after that the relationship was virtually flat (Fig. 1a). There was some residual variation due to species (Fig. 1a), as $M$. agrestis and S. minutus had lower tick loads than expected for their body mass. Tick load was lower in spring than fall. The best model for load of I. ricinus nymph included only a positive effect of (log) body mass (Fig. 1b). Again, the effect was mainly due to an absence of I. ricinus nymphs on small mammals with a body mass below $\sim 10 \mathrm{~g}$. The best model for load of $I$. trianguliceps larvae included only season, with higher loads in spring compared to fall. If adding body mass, estimated effects were positive, but much weaker than for I. ricinus and not significant. The best model for load of I. trianguliceps nymphs included species, (log) body mass and location. I. trianguliceps nymph load tended to increase with body mass $(p=0.052)$, was lower in Apodemus flavicollis than expected from their size, and had higher loads in Førde compared to Angedalen. The effect of body mass was depending on inclusion of $S$. minutus $(n=31)$ without any nymphs.

We confirmed the reversed seasonal pattern fitting a model including larvae of both $I$. ricinus and $I$. trianguliceps in the same model. There was a highly significant interaction between season and tick species $(\mathrm{z}=3.73, p<0.001$, Fig. 2). There was a higher load of $I$. ricinus in fall compared to spring, while the reverse was found for $I$. trianguliceps.

The flagging data revealed far more I. ricinus nymphs in Førde (118 nymphs) than in Angedalen (4 nymphs, $\mathrm{z}=$ $4.14, p<0.001)$, while there was no effect of season $(\mathrm{z}=0.11, p=0.91)$ or year $(\mathrm{z}=-1.53, p=0.13)$. 
Table 1 An overview of samples sizes of small mammals captured during spring and fall 2014 in two study sites (Ang = Angedalen; For = Førde west) in Sogn \& Fjordane county, Norway. The table shows abundances and percentages of Ixodes ricinus and Ixodes trianguliceps life stages on given small mammal species, and the prevalence (Prev) and mean intensity (Int) calculated across tick species and life stages

\begin{tabular}{|c|c|c|c|c|c|c|c|c|c|c|c|c|c|c|c|c|c|}
\hline & \multicolumn{2}{|c|}{ Spring } & \multicolumn{2}{|l|}{ Fall } & \multirow[b]{2}{*}{ Sum } & \multicolumn{2}{|c|}{ 1. ricinus larvae } & \multicolumn{2}{|c|}{ 1. ricinus nymphs } & \multicolumn{2}{|c|}{ I. trianguliceps larvae } & \multicolumn{2}{|c|}{ 1. trianguliceps nymphs } & \multicolumn{2}{|c|}{ 1. trianguliceps adults } & \multirow[t]{2}{*}{ Prev } & \multirow[t]{2}{*}{ Int } \\
\hline & Ang & For & Ang & For & & Sum & $\%$ & Sum & $\%$ & Sum & $\%$ & Sum & $\%$ & Sum & $\%$ & & \\
\hline Apodemus flavicollis & & 3 & & 8 & 11 & 12 & 1.1 & & & 19 & 2.8 & 3 & 4.7 & 1 & 100 & 81.8 & 3.9 \\
\hline Apodemus sylvaticus & 2 & 3 & 12 & 10 & 27 & 222 & 20.4 & 3 & 15 & 67 & 10.0 & 3 & 4.7 & & & 80.0 & 13.4 \\
\hline Microtus agrestis & 1 & 1 & 11 & 7 & 20 & 47 & 4.3 & 12 & 60 & 43 & 6.4 & 2 & 3.1 & & & 82.6 & 5.8 \\
\hline Myodes glareolus & 5 & 1 & 17 & 7 & 30 & 118 & 10.9 & 2 & 10 & 64 & 9.5 & 8 & 12.5 & & & 88.9 & 6.9 \\
\hline Neomys fodiens & & & 2 & 1 & 3 & 6 & 0.6 & & & 8 & 1.2 & 1 & 1.6 & & & 66.7 & 7.5 \\
\hline Sorex araneus & 2 & 4 & 123 & 103 & 232 & 672 & 61.9 & 3 & 15 & 436 & 64.9 & 47 & 73.4 & & & 71.0 & 7.0 \\
\hline Sorex minutus & 2 & & 6 & 23 & 31 & 9 & 0.8 & & & 35 & 5.2 & & & & & 34.2 & 4.9 \\
\hline Unknown & & & 2 & 3 & 5 & & & & & & & & & & & & \\
\hline Sum & 12 & 12 & 173 & 162 & 359 & 1086 & & 20 & & 672 & & 64 & & 1 & & & \\
\hline
\end{tabular}


Table 2 Parameter estimates of tick load in small mammals from negative binomial models. Baseline for species is Sorex araneus. Models for I. ricinus larvae were run excluding and (the best model) including body mass

\begin{tabular}{|c|c|c|c|c|}
\hline & Estimate & Std. error & z & $p$ \\
\hline \multicolumn{5}{|l|}{ I. ricinus larvae } \\
\hline \multicolumn{5}{|l|}{ Excluding body mass } \\
\hline Intercept & 0.4775 & 0.2314 & 2.06 & 0.039 \\
\hline Apodemus flavicollis & 0.4029 & 0.6962 & 0.58 & 0.563 \\
\hline Apodemus sylvaticus & 1.0826 & 0.3675 & 2.95 & 0.003 \\
\hline Microtus agrestis & -0.0725 & 0.3853 & -0.19 & 0.851 \\
\hline Myodes glareolus & 0.7528 & 0.3387 & 2.22 & 0.026 \\
\hline Sorex minutus & -2.8948 & 0.4927 & -5.88 & $<0.001$ \\
\hline Season (spring vs. fall) & -0.705 & 0.3618 & -1.95 & 0.051 \\
\hline \multicolumn{5}{|l|}{ Including body mass } \\
\hline Intercept & -2.6313 & 0.9461 & -2.78 & 0.005 \\
\hline $\log$ (body mass) & 1.5014 & 0.4446 & 3.38 & 0.001 \\
\hline Apodemus flavicollis & -1.4505 & 0.8787 & -1.65 & 0.099 \\
\hline Apodemus sylvaticus & -0.0437 & 0.4891 & -0.09 & 0.929 \\
\hline Microtus agrestis & -2.0303 & 0.6912 & -2.94 & 0.003 \\
\hline Myodes glareolus & -0.7295 & 0.5382 & -1.36 & 0.175 \\
\hline Sorex minutus & -1.4236 & 0.6455 & -2.21 & 0.027 \\
\hline Season (spring vs. fall) & -0.9547 & 0.3593 & -2.66 & 0.008 \\
\hline \multicolumn{5}{|l|}{ I. ricinus nymphs } \\
\hline Intercept & -9.311 & 1.758 & -5.30 & $<0.001$ \\
\hline $\log$ (body mass) & 2.36 & 0.616 & 3.83 & $<0.001$ \\
\hline \multicolumn{5}{|l|}{ I. trianguliceps larvae } \\
\hline Intercept & 0.239 & 0.16 & 1.50 & 0.130 \\
\hline Season (spring vs. fall) & 1.404 & 0.343 & 4.09 & $<0.001$ \\
\hline \multicolumn{5}{|l|}{ I. trianguliceps nymphs } \\
\hline Intercept & -7.227 & 1.959 & -3.69 & 0.000 \\
\hline $\log$ (body mass) & 1.705 & 0.876 & 1.95 & 0.052 \\
\hline Apodemus flavicollis & -3.841 & 1.385 & -2.77 & 0.006 \\
\hline Apodemus sylvaticus & -1.140 & 1.090 & -1.05 & 0.296 \\
\hline Microtus agrestis & -1.778 & 1.477 & -1.20 & 0.229 \\
\hline Myodes glareolus & -0.647 & 1.207 & -0.54 & 0.592 \\
\hline Sorex minutus & -20.20 & 26230.0 & 0.00 & 0.999 \\
\hline Location (Forde vs. Angedalen) & 1.494 & 0.636 & 2.35 & 0.019 \\
\hline
\end{tabular}

\section{Discussion}

Understanding the aggregation of different life stages of Ixodid ticks on different hosts has implications for tick population regulation and epidemiology. The level of co-feeding ticks is particularly important for TBE transmission, but also to some extent for other pathogens $[7,40,41]$. Further, both specialist and generalist Ixodid ticks can play a role in the epidemiology of tickborne diseases [10]. Here, we document a different pattern of host selection by two tick species, one specialist and one generalist, on small mammals. We identify the most important small mammalian hosts for I. ricinus and I. trianguliceps ticks in a northern area with Lyme borrelioses, and we show that body mass is important for explaining tick load within species crossing a $\sim 10$ g body mass threshold, but less so across a range of mammalian hosts above this threshold mass. We also found differing seasonality in larval attachment of the two tick species.

The 4 species of rodents and 3 species of shrews found in this study are all known hosts of the generalist tick, $I$. ricinus, and the specialist tick, I. trianguliceps [18]. Several of them are known pathogen reservoirs in Europe [9], while so far only A. flavicollis and A. sylvaticus have been documented to carry Borrelia afzelii in Norway, likely due to few studies [30, 42]. For I. ricinus, A. sylvaticus was among the main tick hosts in Sweden [43], Poland [24, 25], Romania [23], Italy [7, 20], France [21] and Germany [22], and the species is highlighted as a link between woodland and field habitats $[21,24]$. Also in our study, we found almost twice as high tick infestation intensity on $A$. sylvaticus (13.4 tick/host) compared to the other small mammal hosts, consistent with earlier work [44]. However, only $20.4 \%$ of all $I$. ricinus larvae ticks were found on A. sylvaticus, while the common shrew S. araneus hosted $61.9 \%$. Shrews often dominate in abundance among small mammals, and $S$. araneus had the highest tick load estimate among host species when we controlled for body mass (Table 2). Their small size did, however, result in lower tick intensity per individual (7.5 tick/host) compared to A. sylvaticus, as earlier studies have shown for both $I$. ricinus [44] and I. trianguliceps [45]. Shrews have been highlighted as markedly underestimated as hosts to I. ricinus ticks in endemic areas of the UK [46] and for I. scapularis in USA [47], but have long been recognized as important hosts to $I$. trianguliceps [18]. Our study thus confirms an important role of shrews as a main host to I. ricinus larvae (Table 1). How such patterns may vary across years, due to differences in vegetation and humidity (affecting questing height), or phase of the population cycle of small mammals, remains to be established.

The simultaneous attachment of life stages on the same host is necessary for co-feeding transmission to occur [41]. Only 8 individuals $(2.2 \%)$ had co-feeding I. ricinus larva and nymph. Among these, one $A$. sylvaticus, one $M$. agrestis and one $S$. araneus, had more than 10 larvae and at least 1 nymph as required for TBE transmission. There are currently no reported case of TBE in this region of Norway, while TBEv is now found in the southernmost part of Norway [48]. Co-occurrence of life stages of I. trianguliceps was more common as expected for a rodent specialist. However, we found only a single adult I. trianguliceps (Table 1). The latter may at first sight seem surprising given that adults spend some 10 days feeding. Most likely this is due to low sample size, in particular for larger sized rodents. 

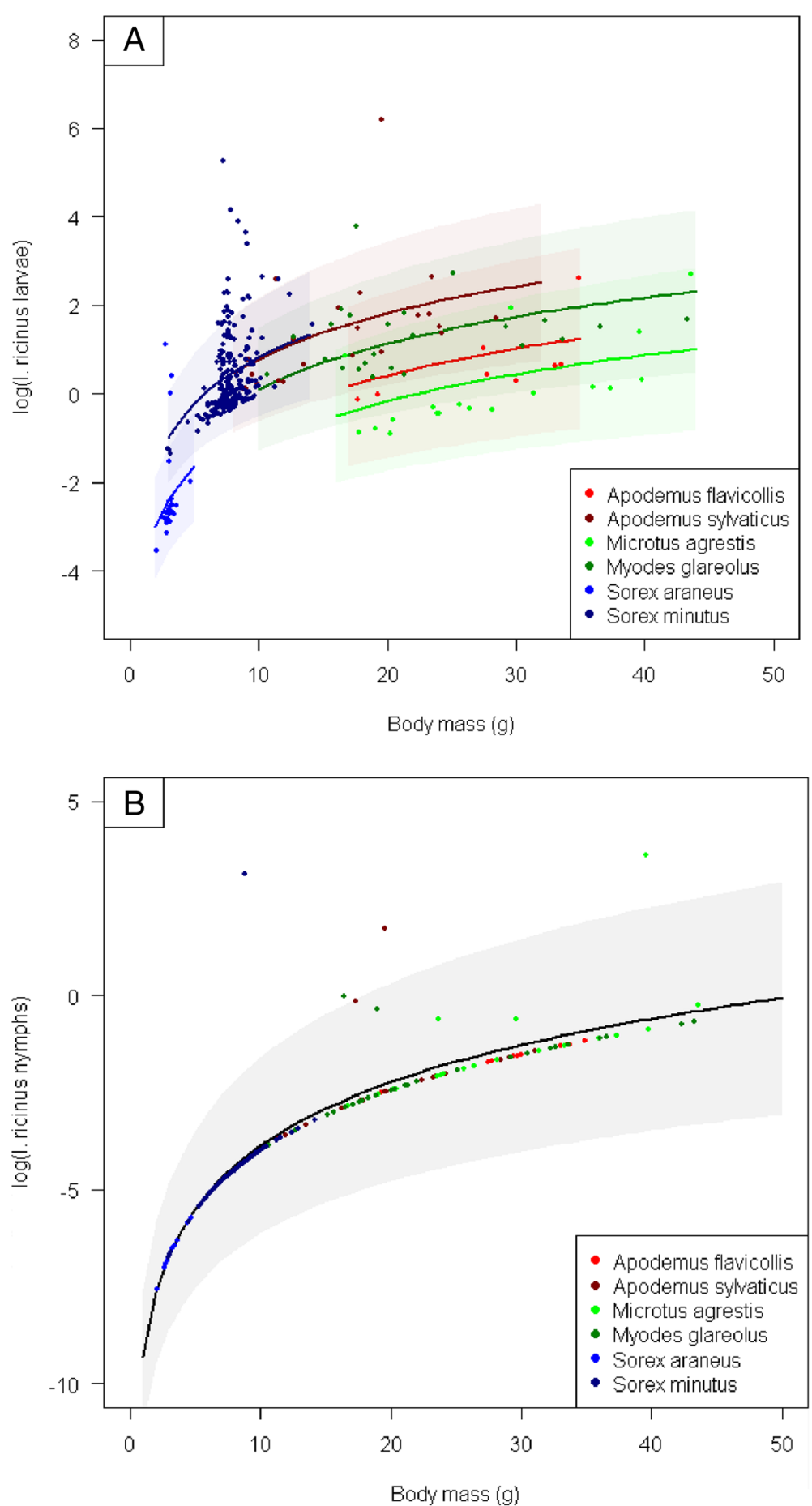

Fig. 1 The number of Ixodes ricinus (a) larvae and (b) nymphs as a function of body mass in 6 species of small mammals captured along the west coast of Norway. Estimated effects are for season fall. Shaded areas are standard error

Several mechanisms may give differences in tick load within and across species, and several of these mechanisms can in turn be linked to body size differences. The greater the size of the animal, the broader the front presented to the vegetation and so the greater the area it will sweep [8]. An animal covering the most ground will pick up the most questing ticks [18, 49], and in addition, home range size is well known to scale to body size when compared across large body size ranges $[50,51]$. This may also depend on trophic niche, and shrews being insectivores may have a different relationship between home range size and body size [52]. Home range sizes of the rodents captured in our 


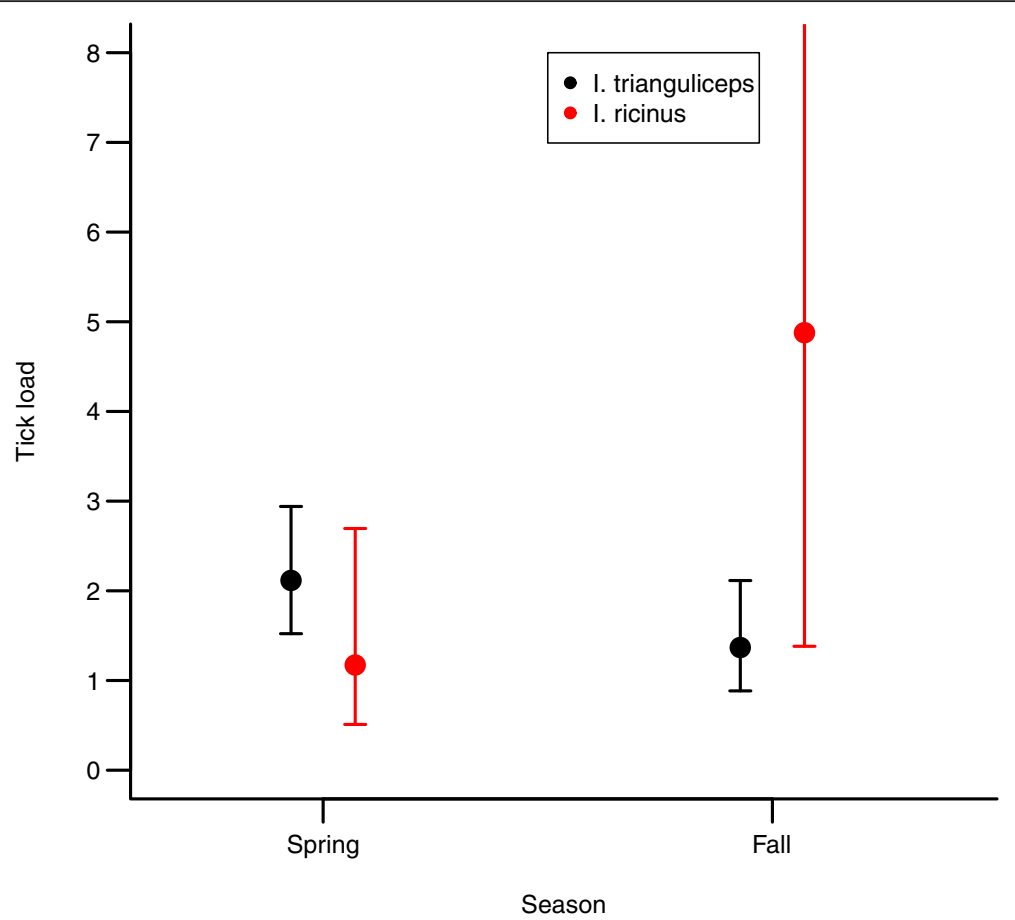

Fig. 2 The number of larvae of Ixodes ricinus and Ixodes trianguliceps on small mammals in spring and fall along the west coast of Norway

study are larger in A. flavicollis (0.75 ha [53]) and A. sylvaticus (1.3 ha [53]) than M. glareolus ( 0.5 ha [54]), and even more so compared to $M$. agrestis (0.07 ha [53]), S. araneus (0.1 ha [55]), and $S$. minutus (0.05 ha [56], 0.2 ha [55]). $S$. minutus tend to have larger home ranges than $S$. araneus $[18,55]$, but nevertheless much fewer ticks. The pattern of tick load is hence not fully consistent with home range size across species. In chipmunks (Tamias striatus), tick load was linked to increased space use [57]. However, the relationship between home range size and body size is often less apparent at the intraspecific level (shown for large mammals $[58,59])$, and space use may not explain the effect of body mass. Age and sex differences in size may be part of the intraspecific body size effect, and sex and age differences in immune defenses may play a role for tick load [60]. However, in A. sylvaticus and M. glareolus, the effect of sex on I. ricinus load was linked to body size rather than to sex [61, 62]. In addition to the direct effect of large body size on exposure, there might also be more active selection by ticks for different hosts. Larval deer ticks $I$. scapularis in the lab showed preference for white-footed mice (Peromyscus leucopus) over chipmunks [63]. Studies of attachment site selection of I. ricinus on larger hosts also suggest an active role of tick movements when on the host [64-66], and hence direct selection for larger individuals may be important.

Different species of ticks may be in competition on hosts [10]. In our study site, the two tick species were almost equally abundant (40 \% I. trianguliceps, $60 \%$
I. ricinus), but we found a different seasonality in their attachment pattern. We found higher load of $I$. ricinus in fall compared to spring, while the reverse was found for I. trianguliceps (Fig. 2). Such a seasonal disparate pattern of attachment between the two tick species, possibly to avoid competition by one or both of the species, may also lead to even more infection levels of pathogens over the season. Further studies are needed from areas with a less even composition of tick species (allopatry) in order to see if the seasonal patterns differ, and if such differences in temporal attachment pattern of different tick species might affect seasonal levels of infection in hosts.

\section{Ethics statement}

Permissions to capture of rodents and shrews were given by the Norwegian Environment Agency (reference 2013/11201) and hence conform to the Norwegian laws and regulations.

\section{Conclusions}

The common shrew S. araneus plays an important quantitative role as a main host to I. ricinus larvae and to both $I$. trianguliceps larvae and nymphs. Larger hosts had higher load of I. ricinus, but increased tick load with increased body mass appeared mainly up to a body mass of $\sim 10 \mathrm{~g}$. The attachment pattern of I. ricinus and I. trianguliceps was partly seasonally asynchronous. These results have implications for understanding tick-borne disease epidemiology in northern forests. 


\section{Appendix 1}

Table 3 Results of model selection of tick load. Best models used for inference are bolded. As there was only 1 I. ricinus nymph in spring, we avoided models with both season and location or species included

\begin{tabular}{|c|c|c|c|c|c|c|c|}
\hline & Species & $\log$ (body mass) & Season & Location & df & $\mathrm{AlC}$ & $\triangle \mathrm{AIC}$ \\
\hline \multirow[t]{14}{*}{ 1. ricinus larvae } & 1 & 1 & 1 & & 10 & 1316.99 & 0.00 \\
\hline & 1 & 1 & 1 & 1 & 11 & 1317.98 & 0.99 \\
\hline & 1 & 1 & & & 9 & 1321.60 & 4.61 \\
\hline & 1 & 1 & & 1 & 10 & 1322.58 & 5.59 \\
\hline & 1 & & 1 & & 9 & 1326.47 & 9.48 \\
\hline & 1 & & & & 8 & 1328.09 & 11.10 \\
\hline & 1 & & & 1 & 9 & 1328.90 & 11.91 \\
\hline & & 1 & 1 & & 5 & 1337.54 & 20.55 \\
\hline & & 1 & 1 & 1 & 6 & 1339.03 & 22.04 \\
\hline & & 1 & & & 4 & 1342.21 & 25.22 \\
\hline & & 1 & & 1 & 5 & 1343.74 & 26.75 \\
\hline & & & 1 & & 4 & 1367.10 & 50.11 \\
\hline & & & & 1 & 4 & 1368.55 & 51.56 \\
\hline & & & 1 & 1 & 5 & 1368.74 & 51.75 \\
\hline \multirow[t]{5}{*}{ 1. ricinus nymphs } & & 1 & & & 4 & 107.16 & 0.00 \\
\hline & & 1 & 1 & & 5 & 108.09 & 0.93 \\
\hline & & 1 & & 1 & 5 & 108.76 & 1.60 \\
\hline & 1 & 1 & & & 9 & 113.41 & 6.25 \\
\hline & & & 1 & & 4 & 123.82 & 16.66 \\
\hline \multirow[t]{12}{*}{ I. trianguliceps larvae } & & & 1 & & 4 & 1220.79 & 0.00 \\
\hline & & & 1 & 1 & 5 & 1220.98 & 0.19 \\
\hline & & 1 & 1 & 1 & 6 & 1221.15 & 0.36 \\
\hline & & 1 & 1 & & 5 & 1221.16 & 0.37 \\
\hline & 1 & 1 & 1 & 1 & 11 & 1225.09 & 4.31 \\
\hline & 1 & 1 & 1 & & 10 & 1225.39 & 4.60 \\
\hline & 1 & & 1 & & 9 & 1225.62 & 4.84 \\
\hline & & 1 & & & 4 & 1231.99 & 11.20 \\
\hline & 1 & 1 & & 1 & 10 & 1234.22 & 13.44 \\
\hline & 1 & 1 & & & 9 & 1234.37 & 13.58 \\
\hline & & & & 1 & 4 & 1237.86 & 17.07 \\
\hline & 1 & & & & 8 & 1240.43 & 19.65 \\
\hline \multirow[t]{12}{*}{ I. trianguliceps nymphs } & 1 & 1 & & 1 & 10 & 271.60 & 0.00 \\
\hline & 1 & 1 & 1 & 1 & 11 & 273.56 & 1.96 \\
\hline & & 1 & & 1 & 5 & 273.99 & 2.39 \\
\hline & 1 & 1 & & & 9 & 275.03 & 3.43 \\
\hline & 1 & 1 & 1 & 1 & 12 & 275.56 & 3.96 \\
\hline & & & & 1 & 4 & 276.74 & 5.13 \\
\hline & & 1 & & & 4 & 276.84 & 5.24 \\
\hline & 1 & 1 & 1 & & 10 & 277.00 & 5.39 \\
\hline & & & 1 & 1 & 5 & 277.21 & 5.61 \\
\hline & 1 & & & & 8 & 277.51 & 5.91 \\
\hline & 1 & & 1 & & 9 & 278.28 & 6.68 \\
\hline & & 1 & 1 & & 5 & 278.79 & 7.19 \\
\hline
\end{tabular}




\section{Competing interests}

The authors affirm that they have no competing interests.

\section{Authors' contributions}

AM designed the study. AM, RB, LQ \&HV carried out data analysis. RB carried out lab and field work. AM and RB drafted the manuscript. All authors read and approved the final version of the manuscript.

\section{Acknowledgements}

This study was funded as part of the ZEWS and TickDeer project over the Research Council of Norway. We are grateful to Anders Herland and Vetle Stigum for field and lab assistance, to Rolf Anker Ims for discussing the study design, to Reidar Mehl and Torbjørn H. Ergon for help in species identification of ticks and small mammals, respectively, to Lene Martinsen for editing the language, and to two anonymous referees for very helpful comments to a previous draft.

\section{Author details}

'Department of Biosciences, Centre for Ecological and Evolutionary Synthesis (CEES), University of Oslo, P.O. Box 1066 Blindern, NO-0316 Oslo, Norway. ${ }^{2}$ Norwegian Veterinary Institute, P.O. Box 750 Sentrum, NO-0106 Oslo, Norway.

Received: 13 October 2015 Accepted: 11 December 2015

\section{Published online: 16 December 2015}

\section{References}

1. Piesman J, Gern L. Lyme borreliosis in Europe and North America. In: Bowman AS, Nuttall PA, editors. Ticks: biology, disease and control. Cambridge: Cambridge University Press; 2008.

2. Randolph SE. Tick-borne encephalitis incidence in central and eastern Europe: consequences of political transition. Microbes and Infection. 2008;10:209-16.

3. Woldehiwet Z. Anaplasma phagocytophilum in ruminants in Europe. Ann NY Acad Sci. 2006;1078:446-60.

4. Shaw DJ, Dobson AP. Patterns of macroparasite abundance and aggregation in wildlife populations: a quantitative review. Parasitology. 1995; 111:S111-33.

5. Brunner JL, Ostfeld RS. Multiple causes of variable tick burdens on smallmammal hosts. Ecology. 2008;89:2259-72.

6. Le Coeur, C, Robert, A, Pisanu, B, Chapuis, JL. Seasonal variation in infestations by ixodids on Siberian chipmunks: effects of host age, sex, and birth season. Parasitol Res. 2015;114:2069-78.

7. Perkins SE, Cattadori IM, Tagliapietra V, Rizzoli AP, Hudson PJ. Empirical evidence for key hosts in persistence of a tick-borne disease. Int J Para. 2003:33:909-17.

8. Milne A. The ecology of the sheep tick, Ixodes ricinus L. Host relationships of the tick: Part 1. Review of previous work in Britain. Parasitology. 1949:39:167-72

9. Gern L, Estrada-Peña A, Frandsen F, Gray JS, Jaenson TGT, Jongejan F, et al. European reservoir hosts of Borrelia burgdorferi sensu lato. Zentralblatt für Bakteriologie. 1998;287:196-204.

10. Estrada-Peña A, de la Fuente J, Ostfeld RS, Cabezas-Cruz A. Interactions between ticks and transmitted pathogens evolved to minimise competition through nested and coherent networks. Scientific Reports. 2015;5:10361.

11. Piesman J, Gern L. Lyme borreliosis in Europe and North America. Parasitology. 2004;129:S191-220.

12. Turner AK, Beldomenico PM, Bown K, Burthe SJ, Jackson JA, Lambin X, et al. Host-parasite biology in the real world: the field voles of Kielder. Parasitology. 2014;141:997-1017.

13. Jahfari S, Coipan EC, Fonville M, van Leeuwen AD, Hengeveld P, Heylen D, et al. Circulation of four Anaplasma phagocytophilum ecotypes in Europe. Parasite Vector. 2014;7:365

14. Bown K, Lambin X, Telford GR, Ogden NH, Telfer S, Woldehiwet Z, et al. Relative importance of Ixodes ricinus and Ixodes trianguliceps as vectors for Anaplasma phagocytophilum and Babesia microti in field vole (Microtus agrestis) populations. Appl Environ Microbiol. 2008;74:7118-25.

15. Brown RN, Lane RS. Lyme disease in California: a novel enzootic transmission cycle of Borrelia burgdorferi. Science. 1992;256:1439-42.

16. Blanarová L, Stanko M, Carpi G, Miklisová D, Víchová B, Mosanský L, et al. Distinct Anaplasma phagocytophilum genotypes associated with Ixodes trianguliceps ticks and rodents in Central Europe. Ticks Tick Borne Dis. 2014;5:928-38.

17. Rar VA, Epikhina TI, Yakimenko W, Malkova MG, Tancev AK, Bondarenko El, et al. Genetic variability of Anaplasma phagocytophilum in ticks and voles from Ixodes persulcatus/Ixodes trianguliceps sympatric areas from Western Siberia, Russia. Ticks Tick Borne Dis. 2014;5:854-63.

18. Randolph SE. Patterns of distribution of the tick Ixodes trianguliceps Birula on its hosts. J Anim Ecol. 1975:44:451-74.

19. Hersh MH, LaDeauS L, Prevaitali MA, Ostfeld RS. When is a parasite not a parasite? Effects of larval tick burdens on white-footed mouse survival. Ecology. 2014;95:1360-9.

20. Rosà R, Pugliese A, Ghosh M, Perkins SE, Rizzoli A. Temporal variation of Ixodes ricinus intensity on the rodent host Apodemus flavicollis in relation to local climate and host dynamics. Vector-Borne Zoonot. 2007;7:285-95.

21. Boyard C, Vourc'h G, Barnouin J. The relationships between Ixodes ricinus and small mammal species at the woodland-pasture interface. Exp Appl Acarol. 2008:44:61-76

22. Matuschka F-R, Fischer P, Musgrave K, Richter D, Spielman A. Hosts on which nymphal Ixodes ricinus most abundantly feed. Am J Trop Med Hyg. 1991;44:100-7.

23. Mihalca A, Dumitrache M, Sandor A, Magdas C, Oltean M, Gyorke A, et al. Tick parasites of rodents in Romania: host preferences, community structure and geographical distribution. Parasites \& Vectors. 2012;5:266.

24. Paziewska A, Zwolinska L, Harris PD, Bajer A, Sinski E. Utilisation of rodent species by larvae and nymphs of hard ticks (Ixodidae) in two habitats in NE Poland. Exp Appl Acarol. 2010;58:112-25.

25. Sinski E, Pawelczyk A, Bajer A, Behnke JM. Abundance of wild rodents, ticks and environmental risk of Lyme borreliosis: a longitudinal study in an area of Mazury lakes district of Poland. Annals of Agricultural and Environmental Medicine. 2006:13:295-300.

26. Jore $S$, Viljugrein $H$, Hofshagen $M$, Brun-Hansen $H$, Kristoffersen A, Nygard $K$, et al. Multi-source analysis reveals latitudinal and altitudinal shifts in range of Ixodes ricinus at its northern distribution limit. Parasite Vector. 2011;4:84.

27. Jaenson TGT, Lindgren $\mathrm{E}$. The range of Ixodes ricinus and the risk of contracting Lyme borreliosis will increase northwards when the vegetation period becomes longer. Ticks Tick Borne Dis. 2011;2:44-9.

28. Medlock JM, Hansford KM, Bormane A, Derdakova M, Estrada-Peña A, George J-C, et al. Driving forces for changes in geographical distribution of Ixodes ricinus ticks in Europe. Parasite Vector. 2013;6:1.

29. Mehl R. The distribution and host relations of Norwegian ticks (Acari, Ixodides). Fauna Norvegica Series B. 1983;30:46-51.

30. Radzijevskaja J, Paulauskas A, Rosef O, Petkevicius S, Mazeika V, Rekasius T. The propensity of voles and mice to transmit Borrelia burgdorferi sensu lato infections to feeding ticks. Vet Parasitol. 2013;197:318-25.

31. Abrahamsen J, Jacobsen NK, Kalliola R, Dahl E, Wilborg L, Påhlsson L. Naturgeografisk region-inndeling av Norden. Nordiske Utredn Ser B. 1977:34:1-135.

32. Myllymäki A, Paasikallio A, Pankakoski E, Kanervo V. Removal experiments on small quadrats as a means of rapid assessment of the abundance of small mammals. Annales Zoologici Fennici. 1971;8:177-85.

33. Hillyard PD. Ticks of north-west Europe. Synopses of the British fauna. London: Natural History Museum; 1996.

34. Margolis L, Esch GW, Holmes JC, Kuris AM, Schad GA. The use of ecological terms in parasitology. Journal of Parasitology. 1982;68:131-3.

35. Vassallo M, Pichon B, Cabaret J, Figureau C, Pérez-Eid C. Methodology for sampling questing nymphs of Ixodes ricinus (Acari: Ixodidae), the principal vector of Lyme disease in Europe. J Med Entomol. 2000;37:335-9.

36. Qviller L, Risnes-Olsen N, Bærum KM, Meisingset EL, Loe LE, Ytrehus B, et al. Landscape level variation in tick abundance relative to seasonal migration pattern of red deer. Plos One. 2013;8:e71299.

37. R Development Core Team R. A language and environment for statistical computing. Vienna: R Foundation for Statistical Computing; 2012.

38. Skaug H, Fournier D, Nielsen A. glmmADMB: Generalized linear mixed models using AD Model Builder. 2006. http://glmmadmb.r-forge.rproject.org Accessed 14 December 2015.

39. Martin TG, Wintle BA, Rhodes JR, Kuhnert PM, Field SA, Low-Choy SJ, et al. Zero tolerance ecology: improving ecological inference by modelling the source of zero observations. Ecol Lett. 2005:8:1235-46.

40. Randolph SE, Green RM, Peacey MF, Rodgers DJ. Seasonal synchrony: the key to tick-borne encephalities foci identified by satellite data. Parasitology. 2000;121:15-23. 
41. Randolph SE, Gern L, Nuttall PA. Co-feeding ticks: epidemiological significance for tick-borne pathogen transmission. Parasitology Today. 1996;12:472-9.

42. Paulauskas A, Ambrasiene D, Radzijevskaja J, Rosef O, Turcinaviciene J. Diversity in prevalence and genospecies of Borrelia burgdorferi senso lato in Ixodes ricinus ticks and rodents in Lithuania and Norway. Int J Med Microbiol. 2008;298(S1):180-7.

43. Tälleklint $L$, Jaenson TGT. Infestation of mammals by Ixodes ricinus ticks (Acari: Ixodidae) in south-central Sweden. Exp Appl Acarol. 1997;21:755-71.

44. Nilsson A, Lundqvist L. Host selection and movements of Ixodes ricinus (Acari) larvae on small mammals. Oikos. 1978;31:313-22.

45. Nilsson A. Host relations and population changes of Ixodes trianguliceps (Acari) in northern Scandinavia. Oikos. 1974;25:315-20.

46. Bown KJ, Lambin X, Telford G, Heyder-Bruckner D, Ogden NH, Birtles RJ. The common shrew (Sorex araneus): a neglected host of tick-borne infections? Vector-Borne Zoonot. 2011:11:947-53.

47. Brisson D, Dykhuizen DE, Ostfeld RS. Conspicuous impacts of inconspicuous hosts on the Lyme disease epidemic. Proc R Soc Lond Ser B. 2008;275:227-35.

48. Andreassen A, Jore S, Cuber P, Dudman S, Tengs T, Isaksen K, et al. Prevalence of tick borne encephalities virus in tick nymphs in relation to climatic factors on the southern coast of Norway. Parasite Vector. 2012;5:177.

49. Milne A. The ecology of the sheep tick, Ixodes ricinus L. Some further aspects of activity, seasonal and diurnal. Parasitology. 1947:38:27-33.

50. Harestad AS, Bunnell FL. Home range and body weight - a reevaluation. Ecology. 1979;60:389-402.

51. McNab BK. Bioenergetics and the determination of home range size. Am Nat. 1963:97:133-40.

52. Kelt DA, Van Vuren DH. The ecology and macroecology of mammalian home range area. Am Nat. 2001;157:637-45.

53. Kelt DA, Van Vuren DH. Home ranges of recent mammals. Ecology. 2015:96:1733.

54. Karlsson AF, Potapov ER. Consistency and change in bank vole (Clethrionomys glareolus) home ranges across a decade. Can J Zool. 1998;76:1329-34.

55. Kollars TM. Home ranges and population densities of shrews (Soricidae) inhabiting a spruce plantation in Bavaria, Germany. Acta Theriol. 1995:40:219-22.

56. Ellenbroek FJM. Interspecific competition in the shrews Sorex araneus and Sorex minutus (Soricidae, Insectivora): a population study of the Irish pygmy shrew. J Zool. 1980;192:119-36.

57. Boyer N, Réale D, Marmet J, Pisanu B, Chapuis J-L. Personality, space use and tick load in an introduced population of Siberian chipmunks Tamias sibiricus. J Anim Ecol. 2010;79:538-47.

58. Rivrud IM, Loe LE, Mysterud A. How does local weather predict red deer home range size at different temporal scales? J Anim Ecol. 2010;79:1280-95.

59. van Beest F, Rivrud IM, Loe LE, Milner JM, Mysterud A. What shapes intraspecific variation in home range size across spatiotemporal scales in a large browsing herbivore? J Anim Ecol. 2011;80:771-85.

60. Hughes VL, Randolph SE. Testosterone depresses innate and acquired resistance to ticks in natural rodent hosts: A force for aggregated distributions of parasites. J Parasitol. 2001;87:49-54.

61. Harrison A, Scantlebury M, Montgomery WI. Body mass and sex-biased parasitism in wood mice Apodemus sylvaticus. Oikos. 2010;119:1099-104.

62. Kiffner $C$, Vor $T$, Hagedorn $P$, Niedrig M, Rühe F. Factors affecting patterns of tick parasitism on forest rodents in tick-borne encephalitis risk areas, Germany. Parasitol Res. 2011;108:323-35.

63. Shaw MT, Keesing F, McGrail R, Ostfeld RS. Factors influencing the distribution of larval blacklegged ticks on rodent hosts. Am J Trop Med Hyg. 2003:68:447-52

64. Handeland K, Qviller L, Vikøren T, Viljugrein H, Lillehaug A, Davidson RK. Ixodes ricinus infestation in free-ranging cervids in Norway - a study based upon ear examinations of hunted animals. Vet Parasitol. 2013;195:142-9.

65. Mysterud A, Hatlegjerde IL, Sørensen OJ. Attachment site selection of life stages of Ixodes ricinus ticks on a main large host in Europe, the red deer (Cervus elaphus). Parasite Vector. 2014;7:510.

66. Kiffner C, Lödige C, Alings M, Rühe F. Attachment site selection of ticks on roe deer, Capreolus capreolus. Exp Appl Acarol. 2011:53:79-94.

\section{Submit your next manuscript to BioMed Central and we will help you at every step:}

- We accept pre-submission inquiries

- Our selector tool helps you to find the most relevant journal

- We provide round the clock customer support

- Convenient online submission

- Thorough peer review

- Inclusion in PubMed and all major indexing services

- Maximum visibility for your research

Submit your manuscript at www.biomedcentral.com/submit
Biomed Central 